\title{
2-(4-Pyridyl)imino nitroxide-tetraphenylporphyrin zinc(II): A chemosensing ensemble for nicotine
}

\author{
HAN HuiFei ${ }^{1}$, ZHANG GuanXin $^{2} \&$ WANG HongMei ${ }^{1 *}$ \\ ${ }^{1}$ Department of Chemistry, China Agricultural University, Beijing 100193, China; \\ ${ }^{2}$ Center for Molecular Sciences, Institute of Chemistry, Chinese Academy of Sciences, Beijing 100190, China
}

Received September 15, 2011; accepted November 17, 2011; published online March 23, 2012

\begin{abstract}
2-(4-Pyridyl)imino nitroxide and tetraphenylporphyrin zinc(II) formed a stable complex by noncovalent bonding in a nonpolar solution. Nicotine displaced 2-(4-pyridyl)imino nitroxide when it was added to a solution of 2-(4-pyridyl)imino nitroxide-tetraphenylporphyrin zinc(II). The fluorescence intensity of tetraphenylporphyrin zinc(II) was altered by sequentially addition of 2-(4-pyridyl)imino nitroxide and nicotine. This was used to develop a new method for detection of nicotine.
\end{abstract}

tetraphenylporphyrin zinc(II), imino nitroxide, detect, nicotine

Citation: Han H F, Zhang G X, Wang H M. 2-(4-Pyridyl)imino nitroxide-tetraphenylporphyrin zinc(II): A chemosensing ensemble for nicotine. Chin Sci Bull, 2012, 57: 1609-1611, doi: 10.1007/s11434-012-5030-5

In recent years, many chemosensing ensembles [1-5] have been reported for the detection of various analytes. In a typical chemosensing ensemble, an indicator first weakly binds to a host through non-covalent and hydrogen bonds. Then, the analyte of interest is added to the system and displaces the indicator from the host, which in turn induces a change in the spectrum of the system. Because the indicator and host are non-covalently bonded, chemosensing ensembles offer many advantages over traditional chemosensors, in which the receptor and reporter units are covalently linked. Using this chemosensing concept, new methods have been developed to detect analytes such as oxalate [6], amino acids [7-9], caffeine [10], cocaine [11], phosphate [12,13], chloride [14], carboxylated and phosphorylated sugars [15], glucose oxidase [16], and chiral carboxylic acids [17].

Nicotine is present in tobacco leaves and cigarette smoke, and has been used in pharmaceutical and synthetic applications and as an insecticide. Detection of nicotine is of particular importance in the tobacco industry and in toxicology [18-20]. Common nicotine detection methods include gas chromatography [21], liquid chromatography [22], and

*Corresponding author (email: whmd@ cau.edu.cn) capillary electrophoresis [23]. Herein, we report a new method for detection of nicotine based on 2-(4-pyridyl)imino nitroxide- tetraphenylporphyrin zinc(II).

The design rationale for the chemosensing ensemble is illustrated in Scheme 1. Porphyrin zinc(II) is highly fluorescent [24], and can easily form complexes with pyridine derivatives. For example, Yamauchi and co-worker [25,26] described formation of a tetraphenylporphyrin zinc(II) complex with 2-(4-pyridyl)nitronyl nitroxide. However, they only studied the spin properties of the excited state of this complex. In an earlier report [27], we detailed the fluorescence quenching caused by nitronyl nitroxide and imino nitroxide. Binding of either nitronyl or imino nitroxide to prophyrin zinc(II) is expected to quench its fluorescence. The absorption spectrum of 2-(4-pyridyl)nitronyl nitroxide shows peaks between $320-400 \mathrm{~nm}$, and overlaps with the fluorescence spectrum of tetraphenylporphyrin zinc(II) (TPPZn). Accordingly, energy transfer will also contribute to quenching of the fluorescence of tetraphenylporphyrin zinc(II). For this reason, 2-(4-pyridyl)imino nitroxide (4-PIN), rather than 2-(4-pyridyl)nitronyl nitroxide, was chosen for the ensemble with TPPZn. Addition of a pyridine derivative to a mixed solution of 4-PIN and TPPZn will 


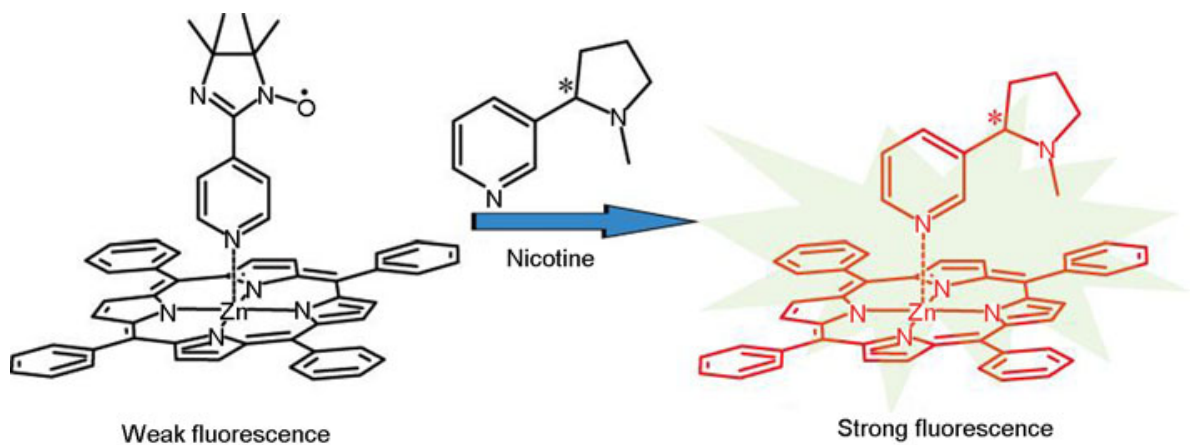

Scheme 1 Fluorescence detection of nicotine.

displace 4-PIN from TPPZn, and the fluorescence of the ensemble will increase. The 4-PIN and TPPZn ensemble, in which 4-PIN is the host and TPPZn is the indicator, can be used for detection of nicotine.

The inset in Figure 1 shows the absorption spectra of TPPZn in the presence of different amounts of 4-PIN in $\mathrm{CH}_{2} \mathrm{Cl}_{2}{ }^{1)}$. As the amount of 4-PIN increased, the two Q-bands of TPPZn gradually red-shifted from 547 to $560 \mathrm{~nm}$ and from 586 to $600 \mathrm{~nm}$. The association constant for 4-PIN and TPPZn in $\mathrm{CH}_{2} \mathrm{Cl}_{2}$ was calculated at $4714 \mathrm{~L} / \mathrm{mol}$ using the Benesi-Hildebrand equation and data from the UV-Vis spectroscopic titration [28]. The absorption spectra of TPPZn in the presence of different amounts of 4-PIN were also measured in solvents of different polarities. In non-polar solvents, such as toluene, the Q-bands red-shifted, which indicates that the stable complex of 4-PIN and TPPZn can be formed in toluene. By contrast, in polar solvents such as $\mathrm{CH}_{3} \mathrm{CN}$, THF and DMF, the absorption spectrum of TPPZn did not change on addition of 4-PIN. This

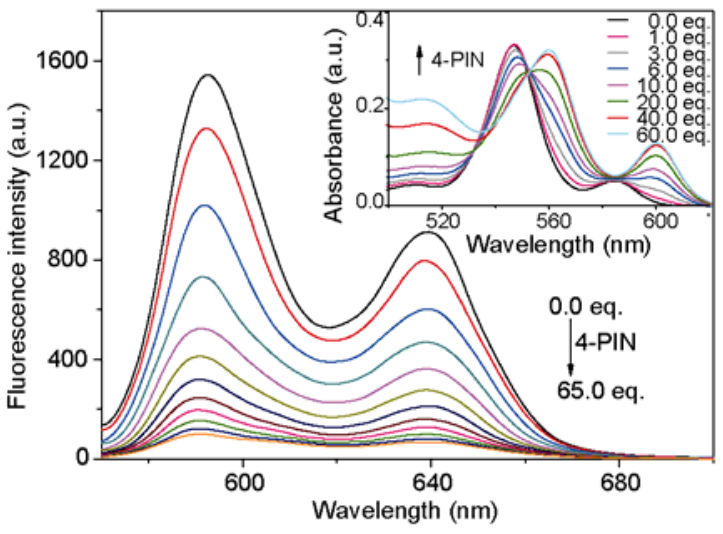

Figure 1 Fluorescence quenching of $2.0 \times 10^{-5} \mathrm{~mol} / \mathrm{L}$ TPPZn by 4-PIN ( 0 to $1.3 \times 10^{-3} \mathrm{~mol} / \mathrm{L}$ ) in $\mathrm{CH}_{2} \mathrm{Cl}_{2}$ with excitation at $556 \mathrm{~nm}$. Inset: absorption spectra of $2.0 \times 10^{-5} \mathrm{~mol} / \mathrm{L}$ TPPZn in $\mathrm{CH}_{2} \mathrm{Cl}_{2}$ with 4-PIN (0 to $1.2 \times 10^{-3}$ $\mathrm{mol} / \mathrm{L})$. result implies that TPPZn and 4-PIN cannot form a stable complex in polar solvents. Therefore, the subsequent fluorescence spectral studies were conducted in $\mathrm{CH}_{2} \mathrm{Cl}_{2}$.

Steady state fluorescence experiments revealed quenching of TPPZn fluorescence by 4-PIN in $\mathrm{CH}_{2} \mathrm{Cl}_{2}$. As shown in Figure 1, 4-PIN efficiently quenched the fluorescence of TPPZn in $\mathrm{CH}_{2} \mathrm{Cl}_{2}$ on excitation at $556 \mathrm{~nm}$. The fluorescence intensity at $592 \mathrm{~nm}$ decreased 14-fold on addition of 65 equivalents of 4-PIN. Because of the coordination of $\mathrm{Zn}$ to $\mathrm{N}$ of the pyridine moiety of imino nitroxide, 4-PIN could quench the fluorescence in two ways. First, because of the presence of imino nitroxide, and second by photoinduced electron transfer (PET) from the imidazole moiety to the porphyrin. 4-PIN efficiently quenched the fluorescence of a $2 \times 10^{-5} \mathrm{~mol} / \mathrm{L}$ TPPZn solution in $\mathrm{CH}_{2} \mathrm{Cl}_{2}$ on excitation at $556 \mathrm{~nm}$.

When nicotine was added to the mixed solution of TPPZn and 4-PIN, the nicotine $\mathrm{N}$ coordinated to $\mathrm{Zn}$, and

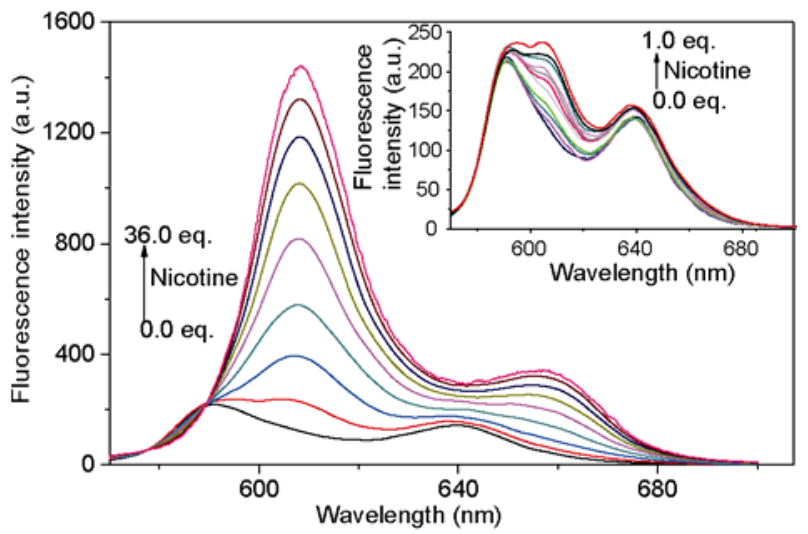

Figure 2 Fluorescence enhancement of the mixed solution of TPPZn $\left(2.0 \times 10^{-5} \mathrm{~mol} / \mathrm{L}\right)$ and 4 -PIN $\left(7.2 \times 10^{-4} \mathrm{~mol} / \mathrm{L}\right)$ by nicotine (from 0 to $7.2 \times 10^{-4} \mathrm{~mol} / \mathrm{L}$ ) in $\mathrm{CH}_{2} \mathrm{Cl}_{2}$. Inset: the fluorescence response of the mixed solution of TPPZn $\left(2.0 \times 10^{-5} \mathrm{~mol} / \mathrm{L}\right)$ and 4 -PIN $\left(7.2 \times 10^{-4} \mathrm{~mol} / \mathrm{L}\right)$ to the low concentration of nicotine from 0 to $2.0 \times 10^{-5} \mathrm{~mol} / \mathrm{L}$.

1) UV-Vis spectra were carried out on a Hitachi U-3010 spectrophotometer using a quartz cell of 10 mm path. Fluorescence spectra were dertermined on a Hitachi F-4500 Fluorescence spectrometer using a fluorescence cell (10 mm). Determination conditions: temperature $20 \pm 1^{\circ} \mathrm{C}$; Ex Slit-5 nm; EM Slit-5 nm; Voltage-950 V. 
displaced 4-PIN. This increased the fluorescence intensity. Figure 2 shows the recovery of the fluorescence of a mixed solution of TPPZn $\left(2 \times 10^{-5} \mathrm{~mol} / \mathrm{L}\right)$ and 4 -PIN $\left(7.2 \times 10^{-4}\right.$ $\mathrm{mol} / \mathrm{L})$ in the presence of different amounts of nicotine $\left(2 \times 10^{-5}\right.$ to $\left.7.2 \times 10^{-4} \mathrm{~mol} / \mathrm{L}\right)$ in $\mathrm{CH}_{2} \mathrm{Cl}_{2}$. The Q-bands redshifted from 592 to $608 \mathrm{~nm}$ and from 639 to $657 \mathrm{~nm}$. When pyridine was added separately to the mixed solution of TPPZn and 4-PIN, the fluorescence intensity of the system increased but by less than with nicotine (Figure S1).

In conclusion, using the quenching effect of 4-PIN, we developed an ensemble, 2-(4-pyridyl)imino nitroxide tetraphenylporphrin zinc(II), which could be used for simple "off-on" fluorescence detection of nicotine. These results could be used to develop new applications for nitroxides. Synthesis of new water-soluble porphyrin-metal-nitroxide systems for selective and sensitive detection of nicotine and its analogs will be investigated in future studies.

This work was supported by the National Natural Science Foundation of China (20802090).

1 Zhu L, Zhong Z, Anslyn E V. J Am Chem Soc, 2005, 127: 42604269

2 Kitamura M, Shabbir S, Anslyn E V. J Org Chem, 2009, 74: 4479_ 4489

3 Buryak A, Zaubitzer F, Pozdnoukhov A, et al. J Am Chem Soc, 2008, 130: 11260-11261

4 Zhang J, Riskin M, Freeman R, et al. ACS Nano, 2011, 5: 5936-5944
5 Kim H N, Guo Z, Zhu W, et al. Chem Soc Rev, 2011, 40: 79-93

6 Tang L, Park J, Kim H, et al. J Am Chem Soc, 2008, 130: 1260612607

7 Folmer-And-ersen J F, Kitamura M, Anslyn E V. J Am Chem Soc, 2006, 128: 5652-5653

8 Leung D, Folmer-Andersen J F, Lynch V M, et al. J Am Chem Soc, 2008, 130: 12318-12327

9 Leung D, Anlyn E V. J Am Chem Soc, 2008, 130: 12328-12333

10 Siering C, Kerschbaumer H, Nieger M, et al. Org Lett, 2006, 8: 1471-1474

11 Stubbs D D, Lee S, Hunt W D. Anal Chem, 2003, 75: 6231-6235

12 Morgan B P, He S, Smith R C. Inorg Chem, 2007, 46: 9262-9266

13 Khatua S, Choi S H, Lee J, et al. Inorg Chem, 2009, 48: 2993-2999

14 Riis-Johannessen T, Schenk K, Severin K. Inorg Chem, 2010, 49: 9546-9553

15 Zhang T, Anslyn E V. Org Lett, 2006, 8: 1649-1652

16 Zhang T, Anslyn E V. Org Lett, 2007, 9: 1627-1629

17 He X, Zhang Q, Wang W, et al. Org Lett, 2011, 13: 804-807

18 Seeman J I, Secor H V. Anal Chem, 1988, 60: 2120-2127

19 Choi M M F, Wu X, Li Y. Anal Chem, 1999, 71: 1342-1349

20 Atkinson W M, Han S M, Purdie N. Anal Chem, 1984, 56: 19471950

21 Stevens N A, Borgerding M F. Anal Chem, 1999, 71: 2179-2185

22 Ciolino L A, Fraser D B, Yi T Y, et al. J Agric Food Chem, 1999, 47: 3713-3717

23 Farre C, Sjoberg A, Jardemark K, et al. Anal Chem, 2001, 73: 12281233

24 Yang L, Cao L, Tian H. J Org Chem, 2006, 71: 8279-8282

25 Ishii K, Fujisawa J, Ohba Y, et al. J Am Chem Soc, 1996, 118: 13079-13080

26 Ishii K, Fujisawa J, Adachi A, et al. J Am Chem Soc, 1998, 120: 3152-3158

27 Wang H M, Zhang D Q, Guo X F, et al. Chem Commun, 2004, 670-671

28 Benesi H A, Hliderbrand J H. J Am Chem Soc, 1949, 71: 2703-2707

Open Access This article is distributed under the terms of the Creative Commons Attribution License which permits any use, distribution, and reproduction in any medium, provided the original author(s) and source are credited.

\section{Supporting Information}

Figure S1 (a) Fluorescence enhancement of the mixed solution of TPPZn $\left(2.0 \times 10^{-5} \mathrm{~mol} / \mathrm{L}\right)$ and $4-\mathrm{PIN}\left(7.2 \times 10^{-4} \mathrm{~mol} / \mathrm{L}\right)$ by nicotine in the presence of triethylamine $(0.036 \mathrm{~mol} / \mathrm{L})$; (b) the difference of fluorescence intensity of the mixed solution of $\mathrm{TPPZn}\left(2.0 \times 10^{-5} \mathrm{~mol} / \mathrm{L}\right)$ and $4-\mathrm{PIN}\left(7.2 \times 10^{-4} \mathrm{~mol} / \mathrm{L}\right)$ by nicotine $\left(\lambda_{\mathrm{ex}}=608 \mathrm{~nm}\right)$ in the presence of triethylamine $(0.036 \mathrm{~mol} / \mathrm{L})$ or not triethylamine in $\mathrm{CH}_{2} \mathrm{Cl}_{2}$.

The supporting information is available online at csb.scichina.com and www.springerlink.com. The supporting materials are published as submitted, without typesetting or editing. The responsibility for scientific accuracy and content remains entirely with the authors. 